\title{
Econometric assessment of a European and Indian free trade agreement
}

\author{
Bodo Herzog ${ }^{1, *}$, Preeta George ${ }^{2}$ \\ ${ }^{1}$ Department of Economics, ESB Business School, Reutlingen University, Reutlingen, Germany \\ ${ }^{2}$ S.P. Jain Institute of Management \& Research (SPJIMR), Bhavans College Campus, Mumbia, India
}

Email address:

Bodo.Herzog@Reutlingen-University.de (B. Herzog), preeta@spjimr.org. (P. George)

\section{To cite this article:}

Bodo Herzog, Preeta George. Econometric Assessment of a European and Indian Free Trade Agreement. Journal of World Economic Research. Vol. 3, No. 1, 2014, pp. 8-14. doi: 10.11648/j.jwer.20140301.12

\begin{abstract}
This article focuses on potential economic implications of a free trade agreement (FTA) between the European Union (EU) and the Indian Federation. The economic implications are evaluated by estimating an extended gravity model for all existing FTAs with the Indian Federation. Moreover, we control for the trade contribution of EU member countries in our econometric model during the period from 1990 until 2008. The results show a significant increase in trade, if there is a free trade agreement between India and another country. Interestingly, we find that India has the largest positive impact from FTAs with more advanced economies. Thus, we reaffirm the potential benefits of trade relationships between the EU and India.
\end{abstract}

Keywords: EU-India, Free Trade Agreement, Gravity Model, JEL Classification: F14, F15, F43, O43

\section{Introduction}

India is an important trade partner for the European Union (EU) and a growing global economic power. It combines a sizable and growing market of more than 1 billion people with a GDP growth rate between 8 to 10 percent. Although today it is far away from the closed market that it used to be twenty years ago, India still maintains both substantial tariff and non-tariff barriers that hamper trade, in particular with EU member countries.

Since 2004, India has become one of the strategic partners of the EU. With its combination of fast growth and a relatively high market protection, India is an obvious partner for one of the EU's FTAs of the new generation started as part of the 'Global Europe Strategy' in 2006 (Sharma 2009). Negotiations were launched in June 2007 and they are still proceeding. The last negotiation round on that issue took place recently, and the negotiations are expected to be finalized soon (EU Commission 2013).

To evaluate trade flows, the gravity equation is a major tool in empirical economic research. It has been used to study the impact of trade flows across international borders and especially in the common market in the European Union. Recently, Helpman, Melitz, and Rubinstein (2006) show in a seminal paper that a modified gravity model considers the impact of trade between potential trading partners more precise. They argue, supported by a theoretical framework, that a lack of trade does not appear randomly. It rather arises from economic conditions such as trading volumes, relationships between countries, and the existence of a common language. We use this extended model to estimate the potential impact of an FTA between India and the EU. Indeed, we find a positive contribution of FTAs.

The article is structured as follows. The next section provides a literature review concerning econometric estimates of trade effects, foreign direct investments (FDIs) and FTAs. In section three, the methodology, data and results will be presented. The implications of the estimation results will then be discussed. Finally, section four concludes the paper.

\section{Literature Review}

Several studies in trade literature have documented a positive relationship between openness, trade agreements and growth in general (Bhagwati and Srinivasan 1985; Frankel and Romer 1999). More recently studies by Barro and Sala-i-Martin (1995), Greenaway, Morgan and Wright (1998) and Baldwin (2003), refer to cross-country regressions, point out that trade protection reduces output growth.

Despite clear evidence of the determinants of economic 
growth, such as trade openness or trade agreements, India has been reluctant to open its markets so far. However, economic growth is only one side of the coin, conditional convergence and catching up to industrial countries are the other. In the past years, economic convergence in terms of GDP per capita in India has been slow despite high GDP growth. According to the World Bank, India ranked eleventh in the world in terms of GDP in 2009. In terms of GDP per capita however, the situation has not been very encouraging: in 1984, India ranked number 89 and in 1994, it was number 80. In 2004, India ranked number 75 in the world. Ben-David (1993) and Sachs and Warner (1995) show that only open economies experience an unconditional economic convergence. Coe and Helpmann (1995) and Coe, Helpmann and Hoffmaister (1997) provide similar evidence of positive growth spillovers but only in open economies. In addition, there is striking evidence by Brunner (2003), that free trade enhances income convergence significantly.

\subsection{Literature on FDIs in India}

There is a large body of literature about the impact of FDIs in India. Singh (2005) conducted an analysis of FDIs between 1991 and 2005. He explored the uneven beginnings of FDIs in India and found that FDI had grown gradually after liberalization in India in 1991. Shiralashetti and Huga (2009) conducted a study on FDIs and economic development spanning the period from 1991 until 2005. They explored that the service sector enjoyed the lion's share of total FDI inflows during this period. According to this study, FDI inflows went up from 409 crore $(\$ 4.09$ billion) between 1991 and 1992 to 17,138 crore $(\$ 171.38$ billion) between 2004 and 2005 respectively. Although FDI inflows into India have increased, this development is very little compared to some developing countries such as China or Brazil. For instance, Sathye (2008) discovered that FDI inflows in India have not grown as fast as in China. A recent study by Siddiqui (2009) analyzes the impact of the financial crisis on FDIs in India. He estimates FDIs and find a decline by 55 percent from $\$ 4.4$ billion in March 2008 to $\$ 2$ billion in March 2009.

Pradhan (2008) and Chakraborty and Basu (2002) used an econometric approach to investigate the link between FDIs and growth for India. They find a positive contribution to GDP growth and evidence that GDP Granger cause FDI inflows in India. Bajpai and Sachs (2000) conducted a meta-analysis and find that despite the existence of a large domestic market, FDI inflows have been relatively low in India. They attribute this to poor infrastructure, high import tariffs and exit barriers for companies. In addition, the limited numbers of special economic zones have a negative impact to economic growth in India, too (Herzog and Weberruß 2011, Sahoo and Mathiyazhagan 2003).

\subsection{Literature on Free Trade Agreements in India}

Our study is mainly devoted to the analysis of free trade agreements (FTAs) between India and other countries and especially advanced economies like the European member states. Regrettably, there are only a few existing FTAs in India. The following subsection briefly summarizes the existing empirical research.

One of the first FTAs was signed between India and Sri Lanka (ISL-FTA) on 28 December 1998 and has been put in effect in March 2000. Mukherji et al. (2003) assessed the impact of the ISL-FTA and find that it has been significant for the period two years prior and after to the liberalization, except for the garment industry. They also show that the ISL-FTA has created new trade. Furthermore, a study by Joshi (2010) proves that the size of the two bilateral trading countries does not matter; both countries benefit equally, independent of their size. The Thailand-India FTA (TI-FTA) was analyzed by Auansakul (2007). However, he confirms that only two out of four product items show an upward trend in India's percentage of imports.

The ASEAN-India free trade agreement (AI-FTA) was analyzed by Rajan and Sen (2004), Schwarz and Willinger (2004), Bhattacharyya and Mandal (2010). In particular Lee et al. (2007) demonstrate positive effects to goods and services but not to financial markets. In addition, Veeramani and Saini (2010) estimate that the AI-FTA has led to an increase in imports, for instance coffee, tea and pepper. This development has been driven mostly by trade creation, which - compared to trade diversification - increases economic efficiency in India. According to Veeramani and Saini (2010), the government's revenue loss due to tariff reduction has been outweighed by the increase in consumer surplus.

Finally, Achterbosch et al. (2008) estimated the possible impact of an agreement between the EU and India. They employed a global economy-wide model and find that the arrangement would lead to a loss for India if it involves only tariff reductions, as the Indian economy is not well integrated into the global markets. Therefore, the expected positive effects could erode under an unsuccessful global trade reform (i.e. Doha Round). The inclusion of agriculture in the agreement, however, would make the deal more equitable for India. Furthermore, Singh and Sengupta (2009) and Sharma and Sengupta (2009) empirically analyzed a further deepening of trade relationships between the EU and India and ascertained that it might lead to losses in India's trade balance.

This paper addresses a similar question but applies a new econometric approach and not just a pure descriptive analysis. Firstly, the impact of existing FTAs between India and other countries will be estimated. Secondly, the potential benefit of an FTA between advanced economies, such as the EU member states, will be measured by applying a common gravity model with dummy and interaction variables. We apply this approach to all trading partners of India. This comprehensive measurement has not been applied before to India. A state-of-the-art panel regression with fixed and random effects will be estimated. The results are highly interesting because our findings close the existing empirical gap on this issue. Moreover, the findings offer new insights 
for policy conclusions. The next section discusses the methodology, the data and the results.

\section{Econometric Methodology, Data and Results}

The aim of this paper is to assess the potential quantitative impact of an FTA between the EU and India. All trade relationships between India and its 20 most important trading partners will be considered. We show that significant and positive trade relationships for the Indian economy with other trading partners do exist due FTAs. Moreover, we study the potential impact of FTAs with Europe. It is worth noting, that the estimations in respect of the EU are made under the current situation, although the bulk of reduction in tariffs is significant but not yet in place and only expected in future.

\subsection{Data}

We use a new dataset for this econometric study. It has been collected from different databases. Some data are from the World Trade Organization, the Indian Department of Industrial \& Policy Promotion and the Global Trade Analysis Project (GTAP), which is a global network of research, conducting quantitative analyses of international trade. The GTAP database is a global database describing bilateral trade patterns. Additional data for FDIs has been collected from national trade accounts, and several dummy variables have been constructed to evaluate the impact of FTAs and the trade relationship with European states. The paper makes use of panel data between 1990 and 2008 and contains the 20 most important trading partners of India. The panel dataset merges all information from different countries and years.

\subsection{Methodology and Econometric Model}

Following the trade model by Melitz (2003), trade volume between countries depends on the one hand on domestic and foreign productivity levels. On the other hand, it is based on a cutoff parameter measuring the size of the foreign market and the transport costs. In the modified model, a cumulative distribution function of firm productivities $\theta$, that has finite support $\left[\theta_{L}, \theta_{H}\right]$, is assumed, with $\theta_{L}$ being the lowest productivity level and $\theta_{H}<\infty$ the highest.

It is evident that if $\theta_{H}$ lies between a country's domestic productivity $\Theta_{D}$ and the cutoff parameter $\Theta_{X}^{l}$, the home firms produce for the home market, but none of the firms finds it profitable to export to country $I\left(\Theta_{D}<\theta_{H}<\Theta_{X}^{l}\right)$ (Helpman, Meltiz, Rubinstein 2006). Moreover, $\theta_{H}$ can be above the export cutoff parameter of some countries $\left(\Theta_{X}^{l}<\theta_{H}\right)$, so that domestic firms may find it profitable to export to some countries but not to others. Generally, the cutoff parameter $\Theta_{X}^{l}$ is smaller the larger the market $l$ and the lower the trading and transport costs with country $l$. The variables that affect the cross-country variation in $\Theta_{X}^{l}$ therefore explain to which foreign country the home country should export. Using firms' optimal pricing strategies, including standard covariates such as distance between the countries and the existence of a common language, we obtain

$$
T_{i j}=\alpha+X_{j}+Y_{i}+\beta d_{i j}+w_{i j}+\epsilon_{i j}
$$

where $X_{j}$ is country $j^{\prime} s$ fixed effect as an exporter, $Y_{i}$ is country $i$ 's fixed effect as an importer, $d_{i j}$ is the distance between the two countries, $w_{i j}$ is an increasing function of the fraction of firms of country $j$ that export to country $i$. The parameter $\epsilon_{i j}$ is an error term that describes the unobserved variation across countries.

It is common in the standard gravity model to estimate equation (1) of trade flows $T_{i j}$, without controlling for the impact of the fraction of exporting firms through $w_{i j}$. However, this is a source of a selection or omitted-variable bias according to Helpman, Melitz and Rubinstein (2006). They show how to apply a novel methods to correct the sample selection bias, by estimation of $T_{i j}$. We use this theoretical underpinning in a gravity model and estimate the impact for India.

In the econometric model, bilateral economic relationships between country $i$ and a number of partner countries $j$ are assumed to be a function of the following variables: GDP of country $j$ and the geographic distance between the two countries. In addition, we collect and design new variables to tackle and measure the unobservable effects as good as possible. Trade volume is our dependent variable. Hence, we estimate the following equation: on the right-hand side we have a constant, two regressors such as gross domestic product (GDP) and distance (DIST). Moreover, several control and dummy variables are implemented: Free Trade Agreement with India (FTA), Neighbor (NBR) i.e. a country with a border to India, Language (LANG), i.e. English, Trade with EU member states (EU) and some additional interaction variables. Finally, we obtain the following regression equation

$$
\begin{array}{r}
\text { Trade }_{i t}=\alpha+\beta_{1} G D P_{i t}+ \\
\beta_{2} D I S T_{i}+\beta_{3} F T A_{i t}+\beta_{4} N B R_{i}+ \\
\beta_{5} L A N G_{i}+\beta_{6} E U+\epsilon_{i t}
\end{array}
$$

where $\epsilon_{i t}$ is the residual with the usual i. i. d. assumption. This equation is a logarithmic specification. We estimate several models with different econometric techniques.

\subsection{Empirical Results and Discussion}

In the following subsection, the regression results will be discussed. Surprisingly, all econometric results are robust even for several model specifications and different econometric techniques. Consequently, the data and the model contain valuable information for numerous conclusions in terms of economic policy. The first results are summarized in Table 1.

To check the robustness and validity of the model, six different models are estimated. Model 1 represents the simple benchmark gravity equation without any control variables. Except the positive sign for distance, all signs are 
as expected. Usually, a negative sign for distance is expected, due to the fact that the farer away a country, the higher the transport costs. There are two explanations why this is not the case here. Firstly, if a country exports and imports very simple and cheap commodities, transport costs are close to zero due to economies of scale. Secondly, India exports many services with ultra-low transport costs. Consequently, for these services the distance does not matter per definition.

Table 1. Gravity Models, Benchmark

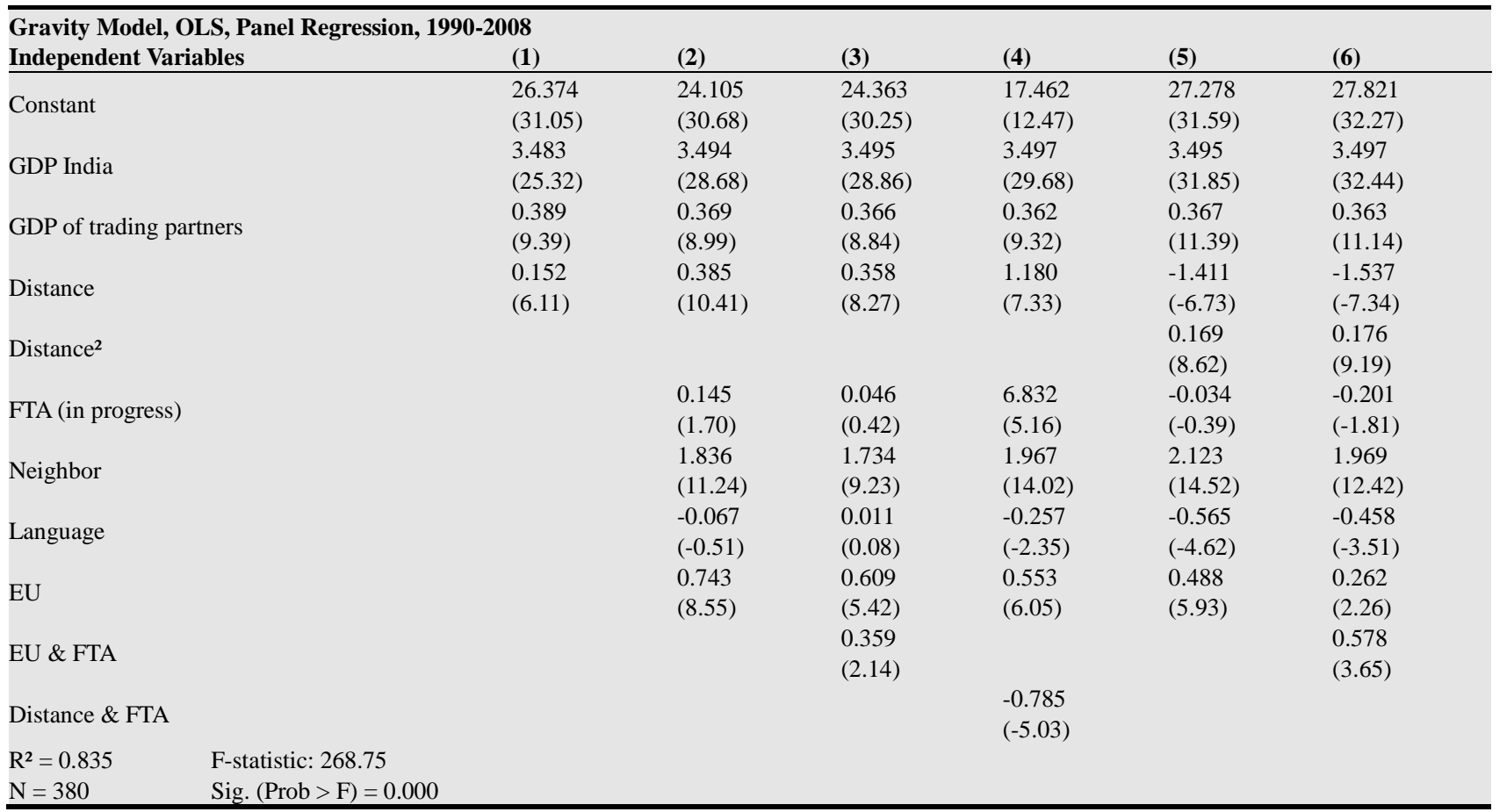

Note: Dependent variable: trade volume. Heteroscedasticity-consistent t-statistics in parentheses. Own estimates (2013).

Table 2. Gravity Models, Panel Regression with Fixed Effects.

\begin{tabular}{|c|c|c|c|c|c|c|}
\hline $\begin{array}{l}\text { Gravity Model, Fixed Effects, Panel Regr } \\
\text { Independent Variables }\end{array}$ & $\begin{array}{l}1990-2008 \\
(1)\end{array}$ & (2) & (3) & (4) & (5) & $(6)$ \\
\hline Constant & $\begin{array}{l}48.215 \\
(152.09)\end{array}$ & $\begin{array}{l}46.010 \\
(94.14)\end{array}$ & $\begin{array}{l}46.276 \\
(90.85)\end{array}$ & $\begin{array}{l}39.390 \\
(31.65)\end{array}$ & $\begin{array}{l}49.188 \\
(90.48)\end{array}$ & $\begin{array}{l}49.744 \\
(88.36)\end{array}$ \\
\hline GDP India & -- & -- & -- & -- & -- & - \\
\hline GDP of trading partners & $\begin{array}{l}0.389 \\
(15.36)\end{array}$ & $\begin{array}{l}0.385 \\
(12.35)\end{array}$ & $\begin{array}{l}0.366 \\
(12.29)\end{array}$ & $\begin{array}{l}0.362 \\
(12.64)\end{array}$ & $\begin{array}{l}0.368 \\
(13.83)\end{array}$ & $\begin{array}{l}0.363 \\
(13.84)\end{array}$ \\
\hline Distance & $\begin{array}{l}0.152 \\
(4.82)\end{array}$ & $\begin{array}{l}0.385 \\
(7.80)\end{array}$ & $\begin{array}{l}0.358 \\
(6.97)\end{array}$ & $\begin{array}{l}1.180 \\
(8.07)\end{array}$ & $\begin{array}{l}-1.411 \\
(-7.44)\end{array}$ & $\begin{array}{l}-1.526 \\
(-8.01)\end{array}$ \\
\hline Distance $^{2}$ & & & & & $\begin{array}{l}0.169 \\
(9.74)\end{array}$ & $\begin{array}{l}0.176 \\
(10.19)\end{array}$ \\
\hline FTA (in progress) & & $\begin{array}{l}0.144 \\
(1.51)\end{array}$ & $\begin{array}{l}0.046 \\
(0.42)\end{array}$ & $\begin{array}{l}6.831 \\
(5.85)\end{array}$ & $\begin{array}{l}-0.035 \\
(-0.40)\end{array}$ & $\begin{array}{l}-0.201 \\
(-2.01)\end{array}$ \\
\hline Neighbor & & $\begin{array}{l}1.837 \\
(8.02)\end{array}$ & $\begin{array}{l}1.734 \\
(7.37)\end{array}$ & $\begin{array}{l}1.968 \\
(8.93)\end{array}$ & $\begin{array}{l}2.124 \\
(10.32)\end{array}$ & $\begin{array}{l}1.970 \\
(9.45)\end{array}$ \\
\hline Language & & $\begin{array}{l}-0.067 \\
(-0.54)\end{array}$ & $\begin{array}{l}0.010 \\
(0.08)\end{array}$ & $\begin{array}{l}-0.257 \\
(-2.08)\end{array}$ & $\begin{array}{l}-0.565 \\
(-4.63)\end{array}$ & $\begin{array}{l}-0.458 \\
(-3.67)\end{array}$ \\
\hline EU & & $\begin{array}{l}0.743 \\
(7.39)\end{array}$ & $\begin{array}{l}0.609 \\
(4.86)\end{array}$ & $\begin{array}{l}0.552 \\
(5.42)\end{array}$ & $\begin{array}{l}0.488 \\
(5.24)\end{array}$ & $\begin{array}{l}0.261 \\
(2.27)\end{array}$ \\
\hline EU \& FTA & & & $\begin{array}{l}0.359 \\
(1.79)\end{array}$ & & & $\begin{array}{l}0.578 \\
(3.25)\end{array}$ \\
\hline Distance \& FTA & & & & $\begin{array}{l}-0.785 \\
(-5.74)\end{array}$ & & \\
\hline $\begin{array}{l}\text { F-statistic: } 126.6 \\
\text { Sig. }(\text { Prob }>\text { F })=0.000\end{array}$ & & & & & & \\
\hline
\end{tabular}

Note: Dependent variable: trade volume. Heteroscedasticity-consistent t-statistics in parentheses. Own estimates (2013).

Model 5 and 6, considers a non-linearity in distance which is the case in the real world. In this case, the sign changes to negative and finally is in line with our expectations. Thus, the more realistic model shows that distance matters for India as well. If the interaction variable "Distance and FTA" is added, a significant coefficient of -0.795 can be found. 
Therefore, distance matters for India especially for the most important trading partners with FTAs.

All other coefficients have the expected signs and being statistically significant at least at the 5 percent level. Most of them are even significant at 1 percent. The only exception, and this is true for almost all models, is the estimated coefficient for language. In simple words: trading with English speaking countries has not a significant impact on India's trade performance. All other factors, such as the GDP of the trading partners, FTAs, trade with EU member states and neighbor countries contribute positively to India's trade performance and domestic growth development. These results are in line with the authors' expectations and the standard gravity model in international trade literature.

The significant positive impact of trade with EU member states is however interesting. In the extended model 6, the contribution of trade with EU countries increases India's trade performance by 26 percent. Hence, trade relationships between the EU and India have beneficial effects for both; in particular for India. Additionally in model 6, the interaction term "EU \& FTA" demonstrates that trade between the EU and India, just with the existing country specific free trade agreements of today, has a high impact to India's economic performance - of about 58 percent. The coefficient is significant at 1 percent and confirms again the positive impact of trade relationships between India and the EU.

In Table 2 and Table 3, we estimate the six models with the panel econometric techniques such as fixed effects and random effects. The results in both tables confirm the authors' findings from the previous estimations of the models in Table 1.

All estimated coefficients in Table 2 and Table 3 are again robust and significant. Additionally, the overall quality of the regression models is confirmed by the high adjusted R-squared and significant F-statistics as well as the Wald-Chi test.

Overall, it can be concluded that India benefits considerably from trading with other FTA countries. Moreover, our results demonstrate that India benefits from new trade relationships even more, if the trading partners are advanced economies. Consequently, we expect a positive impact from a free trade agreement between the EU and India.

Table 3. Gravity Model, Panel Regression with Random Effects.

\begin{tabular}{|c|c|c|c|c|c|c|}
\hline \multicolumn{7}{|c|}{ Gravity Model, Random Effects, Panel Regression, 1990-2008 } \\
\hline Independent Variables & (1) & (2) & (3) & (4) & (5) & (6) \\
\hline Constant & $\begin{array}{l}26.374 \\
(28.65)\end{array}$ & $\begin{array}{l}24.105 \\
(27.40)\end{array}$ & $\begin{array}{l}24.363 \\
(27.39)\end{array}$ & $\begin{array}{l}17.462 \\
(11.97)\end{array}$ & $\begin{array}{l}27.278 \\
(31.70)\end{array}$ & $\begin{array}{l}27.821 \\
(32.06)\end{array}$ \\
\hline GDP India & $\begin{array}{l}3.483 \\
(24.83)\end{array}$ & $\begin{array}{l}3.494 \\
(28.76)\end{array}$ & $\begin{array}{l}3.495 \\
(28.85)\end{array}$ & $\begin{array}{l}3.497 \\
(29.93)\end{array}$ & $\begin{array}{l}3.495 \\
(31.97)\end{array}$ & $\begin{array}{l}3.497 \\
(32.36)\end{array}$ \\
\hline GDP of trading partners & $\begin{array}{l}0.389 \\
(0.025)\end{array}$ & $\begin{array}{l}0.369 \\
(12.06)\end{array}$ & $\begin{array}{l}0.366 \\
(11.99)\end{array}$ & $\begin{array}{l}0.362 \\
(12.29)\end{array}$ & $\begin{array}{l}0.367 \\
(13.35)\end{array}$ & $\begin{array}{l}0.363 \\
(13.34)\end{array}$ \\
\hline Distance & $\begin{array}{l}0.152 \\
(4.77)\end{array}$ & $\begin{array}{l}0.385 \\
(7.62)\end{array}$ & $\begin{array}{l}0.358 \\
(6.81)\end{array}$ & $\begin{array}{l}1.180 \\
(7.85)\end{array}$ & $\begin{array}{l}-1.411 \\
(-7.19)\end{array}$ & $\begin{array}{l}-1.527 \\
(-7.73)\end{array}$ \\
\hline Distance $^{2}$ & & & & & $\begin{array}{l}0.169 \\
(9.41)\end{array}$ & $\begin{array}{l}0.176 \\
(9.83)\end{array}$ \\
\hline FTA (in progress) & & $\begin{array}{l}0.145 \\
(1.48)\end{array}$ & $\begin{array}{l}0.046 \\
(0.41)\end{array}$ & $\begin{array}{l}6.832 \\
(5.69)\end{array}$ & $\begin{array}{l}-0.034 \\
(-0.38)\end{array}$ & $\begin{array}{l}-0.201 \\
(-1.94)\end{array}$ \\
\hline Neighbor & & $\begin{array}{l}1.836 \\
(7.84)\end{array}$ & $\begin{array}{l}1.734 \\
(7.20)\end{array}$ & $\begin{array}{l}1.967 \\
(8.69)\end{array}$ & $\begin{array}{l}2.123 \\
(9.97)\end{array}$ & $\begin{array}{l}1.969 \\
(9.12)\end{array}$ \\
\hline Language & & $\begin{array}{l}-0.067 \\
(-0.53)\end{array}$ & $\begin{array}{l}0.011 \\
(0.09)\end{array}$ & $\begin{array}{l}-0.257 \\
(-2.02)\end{array}$ & $\begin{array}{l}-0.565 \\
(-4.47)\end{array}$ & $\begin{array}{l}-0.458 \\
(-3.53)\end{array}$ \\
\hline EU & & $\begin{array}{l}0.743 \\
(7.23)\end{array}$ & $\begin{array}{l}0.609 \\
(4.75)\end{array}$ & $\begin{array}{l}0.553 \\
(5.28)\end{array}$ & $\begin{array}{l}0.488 \\
(5.06)\end{array}$ & $\begin{array}{l}0.262 \\
(2.19)\end{array}$ \\
\hline EU \& FTA & & & $\begin{array}{l}0.359 \\
(1.75)\end{array}$ & & & $\begin{array}{l}0.578 \\
(3.14)\end{array}$ \\
\hline Distance \& FTA & & & & $\begin{array}{l}-0.785 \\
(-5.59)\end{array}$ & & \\
\hline $\begin{array}{l}\text { F-statistic: -- } \\
\text { Sig. }(\text { Prob > F) = -- }\end{array}$ & $\begin{array}{l}\text { Wald-Chi: } 942.97 \\
\text { Sig. (Prob > chi2 }\end{array}$ & & & & & \\
\hline
\end{tabular}

Note: Dependent variable: trade volume. Heteroscedasticity-consistent t-statistics in parentheses. Own estimates (2013).

\section{Conclusion}

The paper confirms a positive and significant impact of FTAs in India. Moreover, we demonstrate the potential benefits of a FTA between the EU and India. We conclude that further trade integration enhance the economic situation of both the EU and India. The empirical results are in line with other studies in the field of international trade.
Our study has a little limitation in respect of the data horizon. However, the data is reliable and unbiased only until 2008 because of the financial crisis and the European sovereign debt crisis thereafter. In addition, there is only a very limited number of FTAs in India until today. Despite these limitations the estimation results of all models are robust and significant. Nevertheless, further research about the impact of FTAs on India is necessary in the coming years. According to our results, an FTA with the EU has the potential to foster India's economic development. 


\section{Appendix}

* The first author Dr. Bodo Herzog is Professor of Economics at ESB Business School, Reutlingen University, Germany and Research Fellow at MIT, USA. Address: Alteburgstr. 6, D-72762 Reutlingen, Germany.

${ }^{\perp}$ The second author Dr. Preeta George is Professor of Economics at S.P. Jain Institute of Management and Research (SPJIMR), Munshi Nagar, Dadabhai Road, Andheri (W), Mumbai 400098.

The authors would like to thank research assistants Mr. Shwetabh Singh and in particular Ms. Sonja Pfleghaar for editing this paper. In addition, we thank all participants at the international conference "Implications of the Indo-European Free-Trade-Agreement" in Mumbai, India.

\section{References}

[1] Achterbosch, T., M. Kuiper and P. Roza (2008). EU - India free trade agreement: A quantitative assessment. Report 2008-059.

[2] Arora, V. and A. Vamvakids (2004). The Impact of U.S. Economic Growth on the Rest of the World: How Much Does It Matter?. Journal of Economic Integration, Vol. 19, (March), p. 1-18.

[3] Arora, V. and A. Vamvakids (2005). How Much Do Trading Partners Matter for Economic Growth?. IMF Staff Papers, Vol. 52, No. 1, p. 24-40.

[4] Auansakul, A.-A. (2007). Evaluation of Post-TIFTAs' EHS Impact on Trade Diversion: An Econometric Analysis. ITD Research Paper Series.

[5] Bajpai, N. and J.D. Sachs (2000). Foreign Direct Investment in India: Issues and Problems", Development Discussion Paper No. 759 March. Harvard Institute for International Development.

[6] Baldwin, R. (2003). Openness and Growth: What's the Empirical Relationship?. NBER Working Paper No. 9578, Cambridge, Massachusetts.

[7] Barro, R. and X. Sala-i-Martin (1995). Economic Growth. McGraw Hill.

[8] Ben-David, D. (1993). Equalizing Exchange: Trade Liberalization and Income Convergence. Quarterly Journal of Economics, Vol. 108 (August), p. 653-79.

[9] Bhagwati, J.N. and T.N. Srinivasan (1985). Trade Policy and Development. in G. Grossmann (Ed.), Dependence and Interdependence, Essays in Development Economics, Vol. 2, MIT Press.

[10] Bhattacharya, S.K. and B.N. Bhattacharyay (2006). Free Trade Agreement between People's Republic of China and India: Likely Impact and Its Implications to Asian Economic Community. ADB Institute Discussion Paper No. 59.

[11] Bhattacharyya,R. and A. Mandal (2010). Estimating the Impact of the Indo-ASEAN Free Trade Agreement on India's Balance of Trade. Journal of Global Analysis, Vol. 1, No. 1.

[12] Brunner, A.D. (2003). The Long-Run Effects of Trade on Income and Income Growth. IMF Working Paper 03/37,
Washington.

[13] Chakraborty, C. and P. Basu (2002). Foreign direct investment and growth in India: a cointegration approach. Applied Economics, Vol. 34, p. 1061-1073.

[14] Coe, D. and E. Helpmann (1995). International R\&D Spillovers. European Economic Review, Vol. 39, No. 5, pp. 859-87.

[15] Coe, D., E. Helpmann, and A. Hoffmaister (1997). North-South R\&D Spillovers. European Economic Review, vol. 39, No. 5, pp. 859-87.

[16] EU Commission (2013). FTA Negations - Time Schedule. Brussels.

[17] Frankel, J.A. and D. Romer (1999). Does Trade Cause Growth?. American Economic Review, Vol. 89, No. 3, pp. 379-99.

[18] Helpman, E., M.J. Melitz, and Y. Rubinstein (2006). Trading Partners and Trading Volumes. Harvard University, Mimeo.

[19] Herzog, B. and M. Weberruß (2010). What is the Contribution of Indian Special Economic Zones to FDI. Journal of Indo-European Studies, Vol. 1, No. 1, p. 1-16.

[20] Greenaway, D., W. Morgan and P. Wright (1998). Trade Reform, Adjustment and Growth: What Does the Evidence Tell US?. Economic Journal, Vol. 108 (September), pp. 1547-61.

[21] Joshi, V. (2010). An Econometric Analysis of India-Sri Lanka Free Trade Agreement. HEID Working Paper No: 04/2010.

[22] Lee, H.-H., H.-A. Lee, and V.K.-S. Liew (2007). India-ASEAN-5 Economic Integration: Impact of Liberalization. Journal of Applied Economics, Vol. 8 VI, No. 6.

[23] Melitz, M.J. (2003). The Impact of Trade on Intra-Industry Reallocations and Aggregate Industry Productivity. Econometrica. Vol. 71(6), p. 1695-1725.

[24] Mukherji, I.N., T. Jayawardhana and S. Kelegama (2003). Indo-Sri Lanka Free Trade Agreement: An Assessment of Potential And Impact. Mimeo.

[25] Pradhan, R. P. (2008). Does Infrastructure Play a Role in Foreign Direct Investment?. Journal of Financial Economics, Vol. VI, No. 2.

[26] Rajan, R.S. and R. Sen (1994). The New Wave of FTAs In Asia: With Particular Reference To ASEAN, China and India. ADB workshop (July 1-2, Manila).

[27] Sachs, J.D. and A. Warner (1995). Economic Reform and the Process of Global Integration. Brookings Papers on Economic Activity: 1, Brookings Institution, pp. 1-95.

[28] German Council of Economic Experts (2005). Das Erreicht nicht verspielen, Wiesbaden, Germany.

[29] Sahoo, D. and M.K. Mathiyazhagan (2003). Economic Growth In India: Does Foreign Direct Investment Inflow matter?. The Singapore Economic Review, Vol. 48, No. 2, p. 151-171.

[30] Sathye, S. (2008). Investment Development Path Theory and the Case of India. International Review of Business Research Papers, Vol. 4 No. 1, January. 
[31] Schwarz, A. and R. Willinger (2004). Integrating South-east Asia's Economies. McKinsey Quarterly, 2004, Number 1.

[32] Sharma, A. and R. Sengupta (2009). The EU-India FTA in Services and Possible Gender Impact in India: Concern Areas. Paper-IV, Trade and Gender Series, CENTAD and Heinrich Böll Foundation.

[33] Sharma, S. (2009). The EU-India FTA - Critical Considerations in the time of Crisis. CENTAD Working paper.

[34] Shiralashetti, A.S. and S.S. Huga (2009). Foreign Direct Investment and Economic Development of India: A Diagnostic Study. Journal of Managerial Economics, Vol. VII, No. 1.
[35] Siddiqui, K. (2009). Financial Crisis and Its Impact on the Economies of China and India. Research in Applied Economics, ISSN 1948-5433, 2009, Vol. 1, No. 1.

[36] Singh, K. (2005). Foreign Direct Investment in India: A Critical Analysis of FDI from 1991-2005. Centre for Civil Society. New Delhi.

[37] Singh, R. and R. Sengupta (2009). The EU India FTA in Agriculture and Likely Impact on Indian Women. Paper-III, Trade and Gender Series, CENTAD and Heinrich Böll Foundation.

[38] Veeramani, C. and G.K. Saini (2010). Impact of ASEAN-India FTA on India's Plantation Commodities: A Simulation Analysis. Working Paper No. WP-2010-004. 